\title{
SOME DEMOGRAPHIC CHARACTERISTICS OF FRITILLARIA MELEAGRIS (LILIACEAE) IN HUNGARY
}

\author{
Bálint PACsaI ${ }^{1 *}$, Éva Szabó ${ }^{1}$, Éva BIró ${ }^{2}$, Beáta GerencséR ${ }^{2}$, \\ Anita KuczKó ${ }^{1}$ and Judit Bódis ${ }^{1}$ \\ ${ }^{1}$ Department of Plant Sciences and Biotechnology, Faculty of Georgikon, University of Pannonia, \\ H-8360 Keszthely, Festetics u. 7, Hungary; \\ ${ }^{2}$ Balaton Uplands National Park Directorate, H-8229 Csopak, Kossuth u. 16, Hungary; \\ *bpacsai@gmail.com
}

Pacsai, B., Szabó, É., Biró, É., Gerencsér, B., Kuczkó, A. \& Bódis, J. (2019): Some demographic characteristics of Fritillaria meleagris (Liliaceae) in Hungary. - Studia bot. hung. 50(2): 365-378.

\begin{abstract}
Fritillaria meleagris is an endangered Eurasian species with declining populations in most of its distribution area. The significance of the present study is to provide details for improving methods, how age-state structure can be identified in a population. This could help finding the appropriate way of site-management where this species occurs.

We investigated two F. meleagris populations in the western part of Hungary (Gyékényes, Tüskeszentpéter). We grouped the recorded plants into five age-state categories: dormant, juvenile, subadult, vegetative- and reproductive adult. We investigated different plant traits such as plant height, number of leaves, leaf width and leaf length. The relative frequencies of leaf numbers differed significantly between the two sites each year. Generally, the majority of the flowering plants had 5-6 leaves at both sites. Only plant height was positively related to plant reproductive success, but there were no clear trends in leaf width and leaf length.

There are considerable differences in age-state ratios between our sampling sites. The proportion of reproductive plants was noticeably higher in both years in Tüskeszentpéter. Transition into dormant state was regular from all age groups at both sites.
\end{abstract}

Key words: leaf numbers, plant traits, age-state, population flux, fritillary, wet meadows

\section{INTRODUCTION}

Fritillaria meleagris L. is an endangered Eurasian species mostly in all of its distribution area (CSERGÖ \& FRINK 2003). According to the Hungarian Red List the species status was "Near threatened" (NT) in 2007 (KIRÁLY et al. 2007), but the decline became so intense that its conservation value increased tenfold in 2012. Partly because of this F. meleagris was the 'Wildflower of the year' in 2016 in Hungary. Its present decline is coincided with the loss of extensive wet meadows due to the intensification of agricultural practices almost in the whole range (Grootjans et al. 1996, ZYCH 2014). Although, the species has a broad phytocoenological amplitude, covering swamps, moist grasslands, hedges, and 
woodlands (MAGNES et al. 2013), the majority of the populations grow in seasonally flooded grasslands (Horst HUIS et al. 1994, ILIJANić et al. 1998), which have not been ploughed or improved for several hundred years (TATARENKO $e t$ al. 2013). In Hungary, F. meleagris is known as a species of riparian woodlands, however it forms large populations only on meadows which appear after woodland clearance (BIró et al. 2018, MESTERHÁZY 2013).

Quantitative plant traits, particularly the number of leaves are commonly used for the evaluation of condition and determining age-state of plants (GATSUK et al. 1980). According to the demographic studies in Sweden at the Kungsängen Nature Reserve the performance of individual plants may change between juvenile, subadult, vegetative adult and reproductive adult age-states over time as a consequence of the succession of the bulbs (ZHANG 1983). Following ZHANG (1983) categories since 1999 a survey programme has been carried out on the dynamics of a large population of F. meleagris in the North Meadow National Nature Reserve (Wiltshire, United Kingdom). In this population some opposing trends were described, which is likely the result of flowering plants transitioning into the adult vegetative group and back (TATARENKO et al. 2013).

F. meleagris is a characteristic species of the western-southwestern part of Hungary, with large populations on the meadows along the river Zala, Kerka, and Rába (KEVEY 2013 and 2018). We investigated there 2 populations in wet meadows to determine: 1) Zhang's age-state system based on the leaf numbers. Whether there is any plant trait (e.g. plant height, length or width of leaves) which informs us about the age-state of the plants 2) Are there similarities or differences in the main demographic characteristics of the populations which are very close together compared to the whole range of distribution of the species?

Our investigations could be useful for conservational point of view, considering the declining trend of the populations nearly in its whole distribution range as well as in Hungary.

\section{MATERIAL AND METHODS}

\section{Study sites}

We investigated two populations in the western part of Hungary, situated on floodplain meadows. Tüskeszentpéter (now part of Zalaszentgrót) is on the floodplain of the River Zala, Gyékényes is on the floodplain of the River Dráva (Fig. 1). In the text under the name of the villages we mean the localities of the $F$. meleagris populations, i.e. wet meadows, not the settlement. 


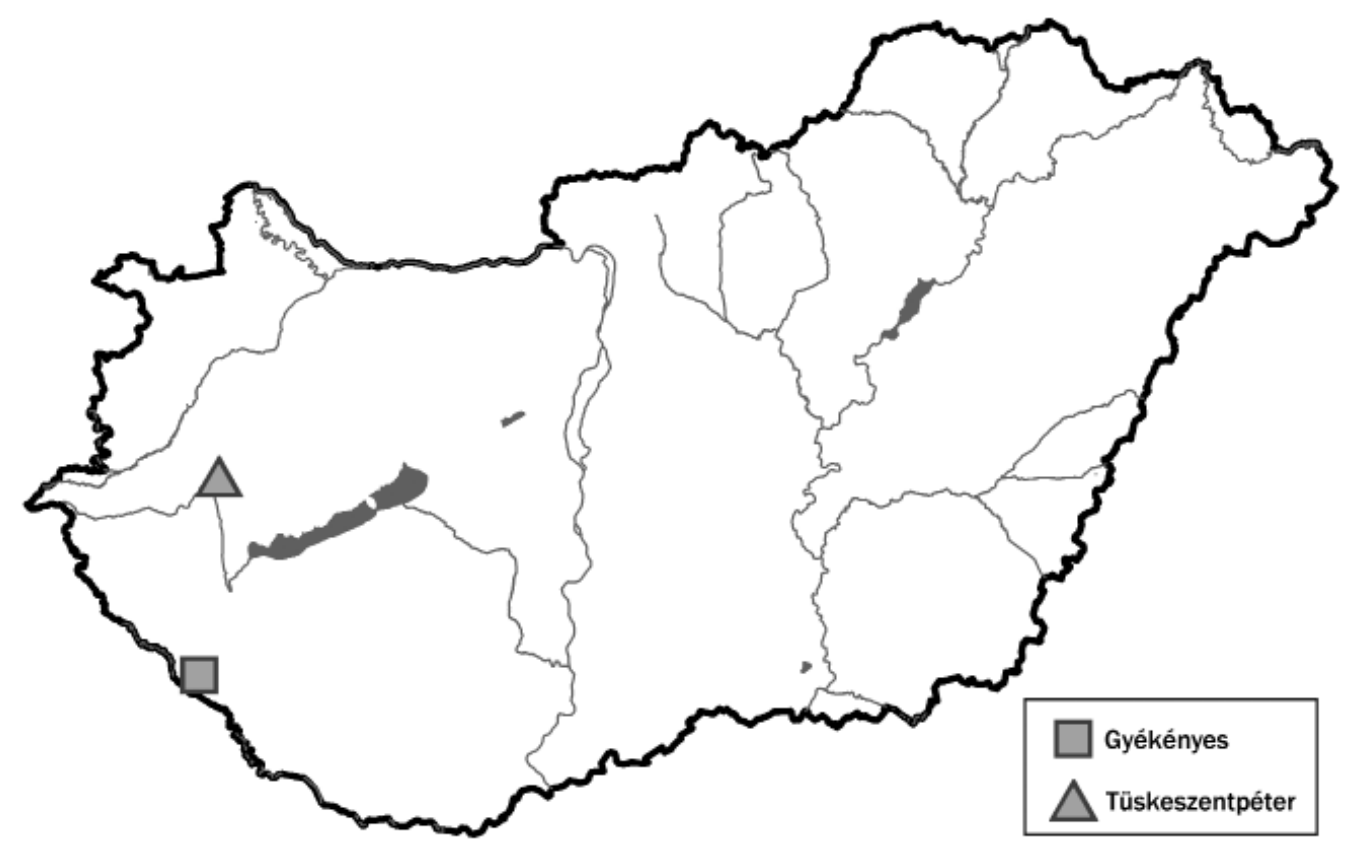

Fig. 1. Sample sites.

\section{Methods}

We fixed two transects made up of 12 quadrats each in both meadows in 2017 and marked every individual with nails equipped with numbered $1 \mathrm{~cm} \times$ $1 \mathrm{~cm}$ stainless plates which were positioned $2 \mathrm{~cm}$ to the left of the plants. Then we located every individual in $1 \times 1 \mathrm{~m}$ square quadrats which were divided into $10 \mathrm{~cm}$ grid squares by strings both across and up quadrat. We noted for every $F$. meleagris plant whether it is flowering, the number of leaves, measured the height of the tallest point (usually top leaf stretched out), width and length (the latter was recorded only in 2018) of the top leaf. These measures were taken during flowering (Gyékényes: 01.04.2017, Tüskeszentpéter: 02.04.2017). We repeated the counting and measuring in 2018, but in the late flowering period (Gyékényes: 28.04.2018; Tüskeszentpéter: 06.05.2017), because before the meadows were waterlogged for a prolonged time. There were 'missing' plants (which did not appear above ground that year) and 'new' ones (which weren't marked in the previous year) as well in 2018 ( Table 1).

We compared the distributions of leaf numbers using Kolmogorov-Smirnov test and we used Tukey-test to identify groups on the basis of morphological data. For the statistical analyses we used IBM SPSS Statistics 23.0. 
Table 1. Number of measured F. meleagris individuals (which have a shoot) in 2017 and 2018. The number of all plants, including 'missing' ones is indicated in parentheses.

\begin{tabular}{lcc}
\hline Sampling site & 2017 & 2018 \\
\hline Gyékényes & 231 & $149(275)$ \\
Tüskeszentpéter & 157 & $83(172)$ \\
\hline
\end{tabular}

Following ZHANG (1983) we grouped the plants into four age-states: juvenile (plants with only one leaf), subadult (two or three leaves, not flowering), adult vegetative (four or more leaves, without flower) and adult reproductive (flowering). Furthermore, we stated a fifth, 'dormant' age-state. Dormant individuals in 2017 had no shoots in 2017, but shoot was developed in 2018. We considered plants dormant in 2018, which were marked in 2017 but there were no shoots in 2018. Based on the surveying method of $Z_{\text {HANG }}$ (1983) we omitted the category of 'seedlings' in our survey, because the quantitative counting of firstyear seedlings is practically unfeasible in the field. As F. meleagris plants could be dormant for more than one subsequent year (ZHANG 1983), we did not know whether a plant is dormant or perished in 2018, so we also did not calculate on mortality during the survey.

\section{RESULTS}

\section{Proportion of leaf numbers}

In Tüskeszentpéter, the number of leaves varied between 1-9 in 2017 and 2-7 in 2018 (Fig. 2). Most individuals in the population had five or six leaves each year (71\% in $2017,66 \%$ in 2018$)$.

In Gyékényes the number of leaves of individuals varied between 1-9 in 2017 and 1-8 in 2018 (Fig. 3). Most individuals had four or five leaves (52\% in $2017,47 \%$ in 2018 ) and many individuals had one leaf (19\% in $2017,20 \%$ in 2018) in the two years. The proportion of individuals with two leaves was remarkably low at both sites each year or was not even recorded (Tüskeszentpéter, 2017).

We found that there were no significant differences between the distributions of the number of leaves in 2017 and 2018 at each locality $(\alpha=0.909$ for Tüskeszentpéter and $\alpha=0.247$ for Gyékényes), but there were significant differences between the data of the two localities in both years $(\alpha<0,001$ in both 2017 and 2018). 


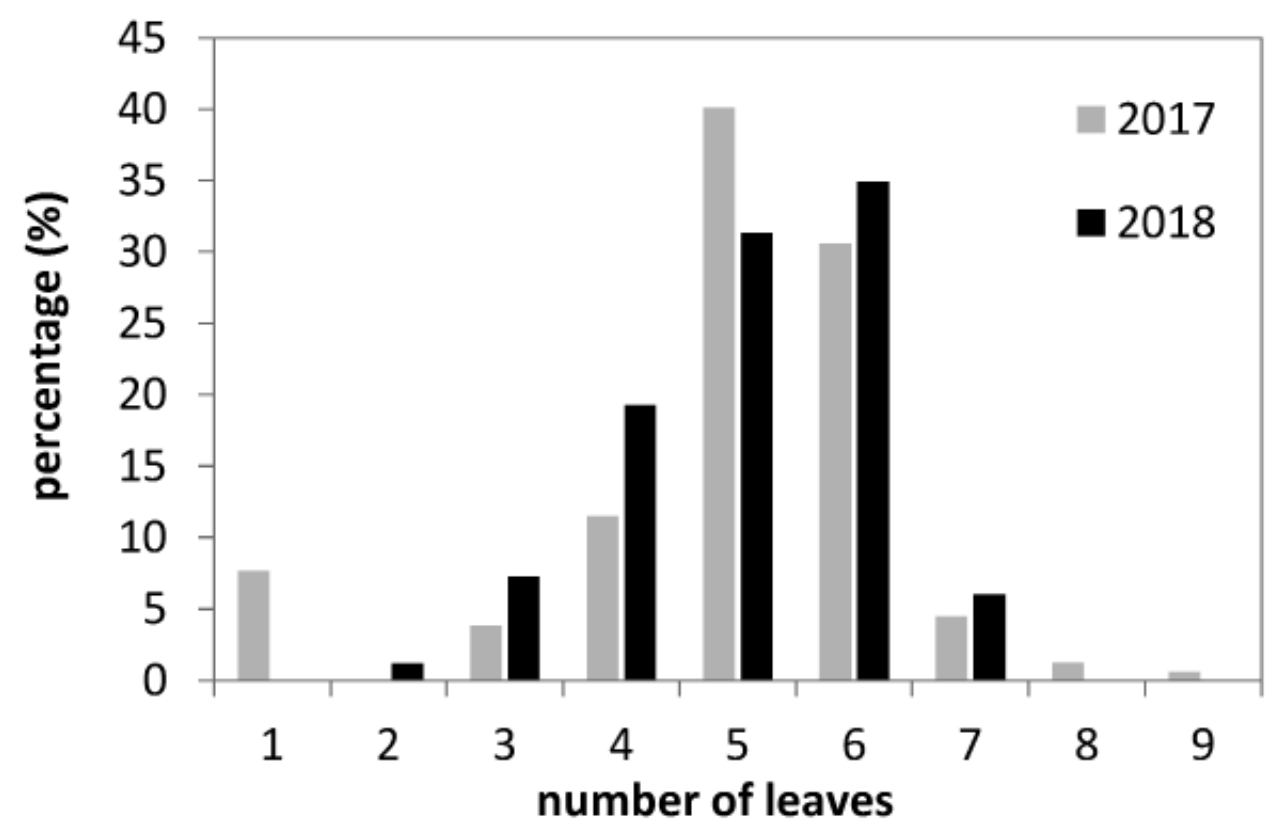

Fig. 2. Relative frequencies of leaf numbers in Tüskeszentpéter in the two years of study (2017: $\mathrm{n}=157 ; 2018: \mathrm{n}=83)$.

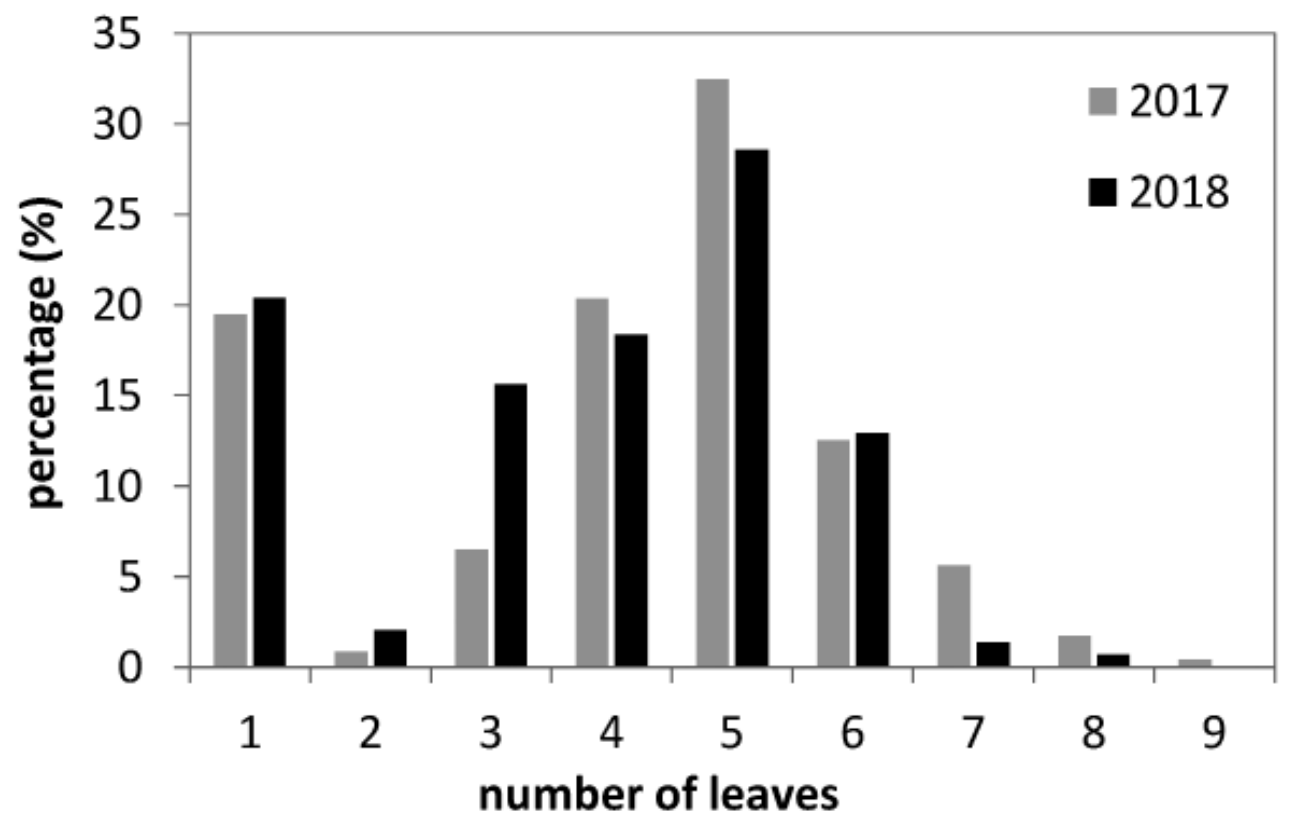

Fig. 3. Relative frequencies of leaf numbers of individuals in Gyékényes in the two years of study (2017: $\mathrm{n}=231 ; 2018: \mathrm{n}=149)$. 
Number of leaves in the case of reproductive plants

The number of leaves of reproductive adults varied between 3 and 7. In Gyékényes in both years most reproductive adults had five leaves (60 and 58\%) (Fig. 4). In Tüskeszentpéter in 2017 the largest proportion of the individuals nearly half of them (49\%) - had also five leaves, but next year most individuals had six leaves (47\%) (Fig. 5).

The percentage of reproductive adults related to the total number of plants with 3 to 7 leaves (including the subadult and vegetative adults as well) was high in Tüskeszentpéter in both years (2017: 66\%, $\mathrm{n}=142 ; 2018: 65 \%, \mathrm{n}=82)$. In comparison, in Gyékényes their proportion was much lower in both years (2017: $29 \%, \mathrm{n}=179 ; 2018: 23 \%, \mathrm{n}=114)$.

\section{Age-state structure}

In Tüskeszentpéter, the proportion of adults (including both vegetative and reproductive adults) was rather high ( $81 \%$ ) in 2017 , of which $68 \%$ were reproductive adult ( $55 \%$ of the total number of plants). Next year the proportion of adults was much lower (45\%), of which $69 \%$ were reproductive adult (31\% of the total number of plants). The proportion of plants in dormant-state differed considerably from year to year at this site: it was 9\% in 2017 and 52\% in 2018 (Fig. 6).

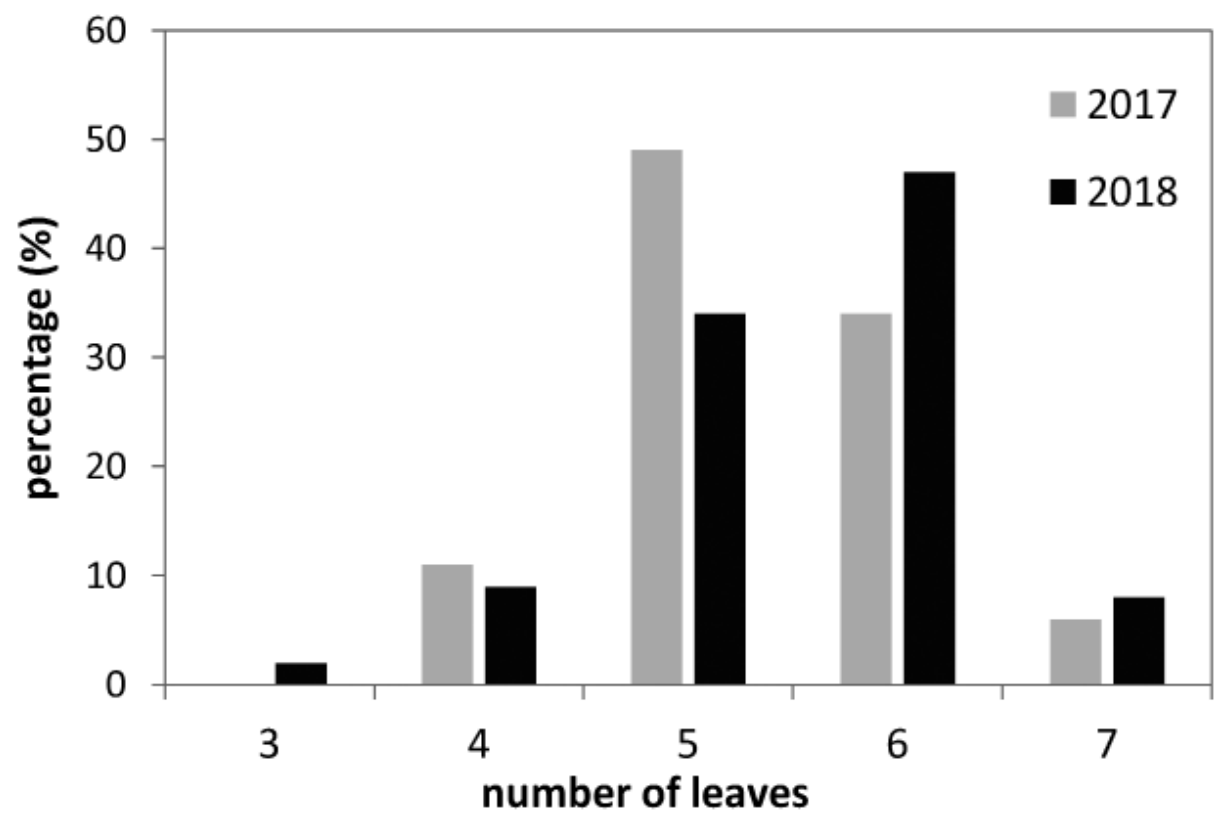

Fig. 4. Relative frequencies of leaf numbers in the case of reproductive plants in Tüskeszentpéter in the two years of study $(2017: \mathrm{n}=94 ; 2018: \mathrm{n}=53)$. 


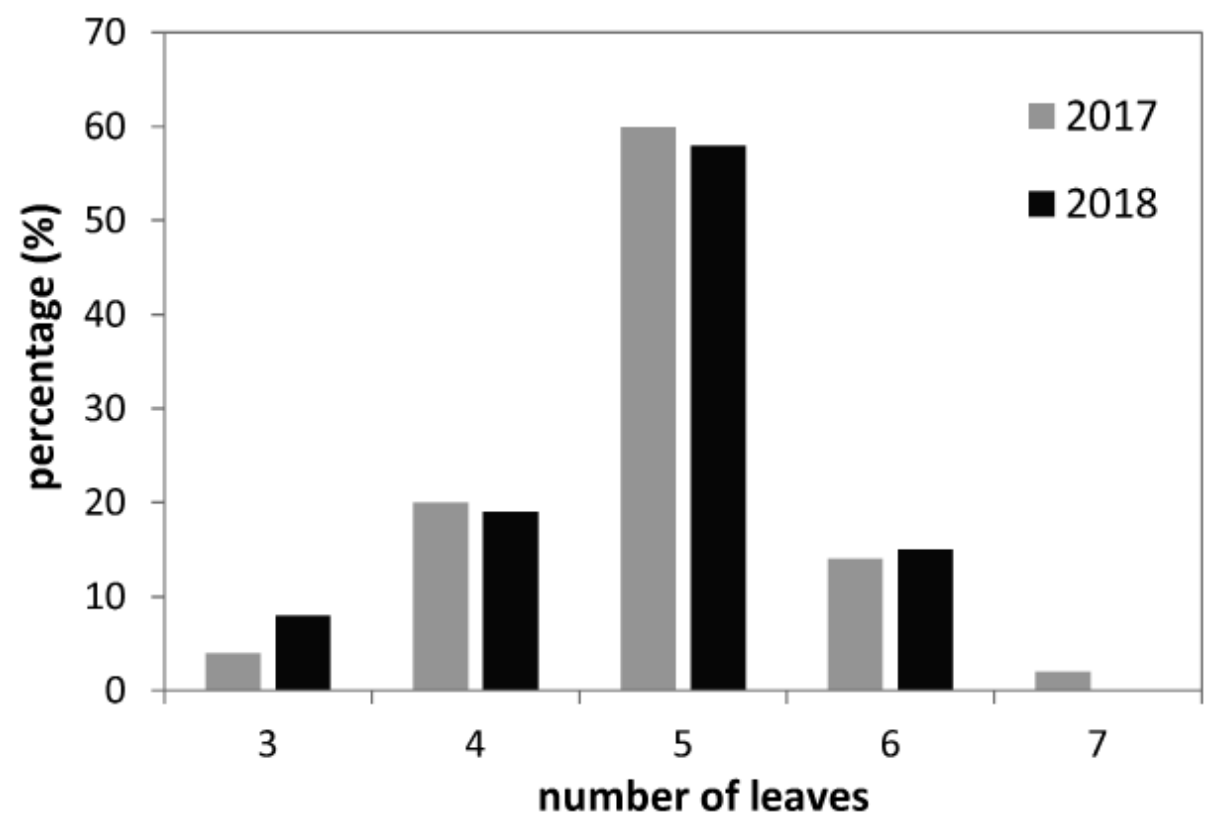

Fig. 5. Relative frequencies of leaf numbers in the case of reproductive plants in Gyékényes in the two years of study $(2017: \mathrm{n}=51 ; 2018: \mathrm{n}=26)$.

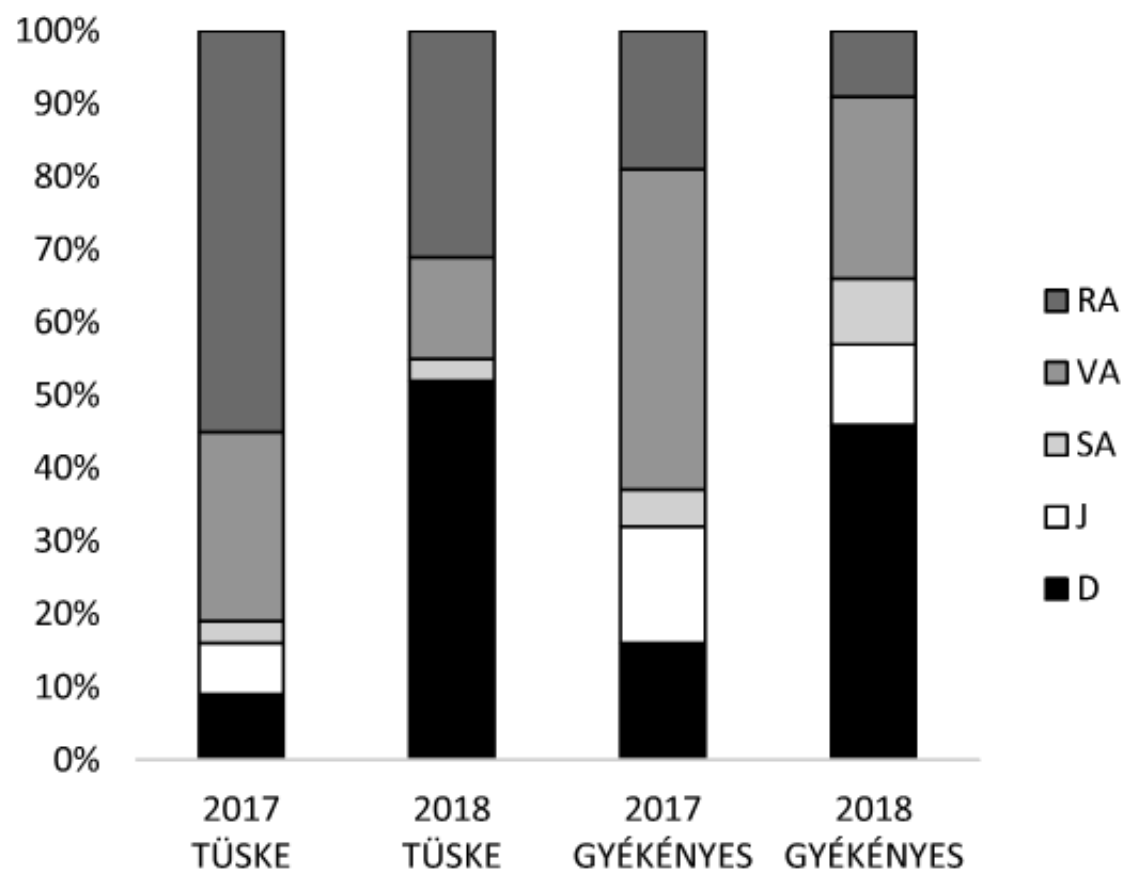

Fig. 6. Age-state structure of the populations in Tüskeszentpéter (TÜSKE) and Gyékényes in 2017 and 2018 ( $\mathrm{D}=$ dormant, $\mathrm{J}=$ juvenile, $\mathrm{SA}=$ subadult, $\mathrm{VA}=$ vegetative adult, $\mathrm{RA}=$ reproductive adult $)$. 
In Gyékényes high proportion (44\%) of vegetative adults was recorded in 2017 and $19 \%$ of the total number of individuals were reproductive in that year. The proportions of juveniles and plants in dormant state were close to equal (16$16 \%)$. Next year rates of dormancy were much higher (46\%) and the proportion of reproductive adults was rather low (9\%) (Fig. 6).

\section{Plant traits of different age-state categories}

Reproductive adults were significantly taller than plants in all other groups, there were no significant differences in the plant height of the other 4 age-states (Table 2).

Table 2. Mean values of the plant heights $(\mathrm{cm})$ of different age-states (mean $\pm S D)$. Characters in the superscript show the result of Tukey's test $(\mathrm{J}=$ juvenile, $\mathrm{SA}=$ subadult, $\mathrm{VA}=$ vegetative adult,

$\mathrm{RA}=$ reproductive adult $)$.

\begin{tabular}{c|cc|cc}
\hline & \multicolumn{2}{|c|}{ Tüskeszentpéter } & \multicolumn{2}{c}{ Gyékényes } \\
& 2017 & 2018 & 2017 & 2018 \\
\hline J & $14.17 \pm 2.96^{\mathrm{a}}$ & no data & $15.46 \pm 3.22^{\mathrm{a}}$ & $12.92 \pm 3.87^{\mathrm{a}}$ \\
SA & $16.17 \pm 2.66^{\mathrm{ab}}$ & $21.13 \pm 5.66^{\mathrm{a}}$ & $14.61 \pm 2.60^{\mathrm{a}}$ & $14.26 \pm 3.31^{\mathrm{a}}$ \\
VA & $19.17 \pm 3.30^{\mathrm{b}}$ & $23.25 \pm 5.18^{\mathrm{a}}$ & $18.31 \pm 3.35^{\mathrm{b}}$ & $15.45 \pm 3.25^{\mathrm{a}}$ \\
RA & $27.17 \pm 4.28^{\mathrm{c}}$ & $29.42 \pm 4.84^{\mathrm{b}}$ & $28.31 \pm 6.00^{\mathrm{c}}$ & $24.08 \pm 10.26^{\mathrm{b}}$ \\
\hline
\end{tabular}

We got overlapping groups in the case of leaf width in Tüskeszentpéter and in Gyékényes in both years. There were neither well differentiated groups nor differences regarding leaf length (Table 3 ).

Table 3. Mean values of leaf width and leaf length of different age-states (mean $\pm S D$ ). Characters in the superscript show the result of Tukey's test $(\mathrm{J}=$ juvenile, $\mathrm{SA}=$ subadult, $\mathrm{VA}=$ vegetative adult, $\mathrm{RA}=$ reproductive adult).

\begin{tabular}{c|cccc|cc}
\hline \multirow{4}{*}{} & \multicolumn{4}{|c|}{ leaf width $(\mathrm{cm})$} & \multicolumn{2}{c}{ leaf length $(\mathrm{cm})$} \\
& \multicolumn{2}{|c}{ Tüskeszentpéter } & \multicolumn{2}{c|}{ Gyékényes } & Tüskeszentpéter & Gyékényes \\
& 2017 & 2018 & 2017 & 2018 & 2018 & 2018 \\
\hline J & $0.50 \pm 0.23^{\mathrm{a}}$ & no data & $0.56 \pm 0.26^{\mathrm{ab}}$ & $0.37 \pm 0.11^{\mathrm{a}}$ & no data & $12.00 \pm 4.00^{\mathrm{ab}}$ \\
SA & $0.57 \pm 0.23^{\mathrm{ab}}$ & $0.45 \pm 0.13^{\mathrm{a}}$ & $0.49 \pm 0.20^{\mathrm{a}}$ & $0.53 \pm 0.28^{\mathrm{b}}$ & $9.00 \pm 2.45^{\mathrm{a}}$ & $13.00 \pm 3.00^{\mathrm{b}}$ \\
VA & $0.73 \pm 0.18^{\mathrm{bc}}$ & $0.48 \pm 0.18^{\mathrm{a}}$ & $0.63 \pm 0.19^{\mathrm{bc}}$ & $0.52 \pm 0.19^{\mathrm{b}}$ & $12.15 \pm 4.00^{\mathrm{a}}$ & $12.00 \pm 3.00^{\mathrm{ab}}$ \\
RA & $0.79 \pm 0.17^{\mathrm{c}}$ & $0.51 \pm 0.13^{\mathrm{a}}$ & $0.70 \pm 0.17^{\mathrm{c}}$ & $0.46 \pm 0.20^{\mathrm{ab}}$ & $12.80 \pm 3.57^{\mathrm{a}}$ & $10.00 \pm 4.00^{\mathrm{a}}$ \\
\hline
\end{tabular}




\section{Population flux}

At both sites, there were individuals from every age state which entered into dormant phase in 2018 (Tables 4 and 5), the only exception was the juvenile age-state in Tüskeszentpéter, because we could not find any plants of this category in 2017. A high proportion of the plants which became dormant in 2018 were vegetative and reproductive adult in 2017 at each site, and many of them were juvenile in Gyékényes (Table 4). In Tüskeszentpéter nearly two-thirds of individuals, which were recorded as dormant plants in 2017 entered into vegetative-state and a quarter of them into reproductive-state next year (Table 5). On the other hand in Gyékényes the largest proportion of individuals which had been dormant in 2017 emerged as a juvenile in 2018 (Table 4) and there were many vegetative and reproductive adults as well, which had been dormant the year before (Table 6).

Table 4. Population flux from 2017 to 2018 in Gyékényes by the age-state of plants in 2017 ( $\mathrm{D}=$ dormant, $\mathrm{J}=$ juvenile, $\mathrm{SA}=$ subadult, $\mathrm{VA}=$ vegetative adult, $\mathrm{RA}=$ reproductive adult).

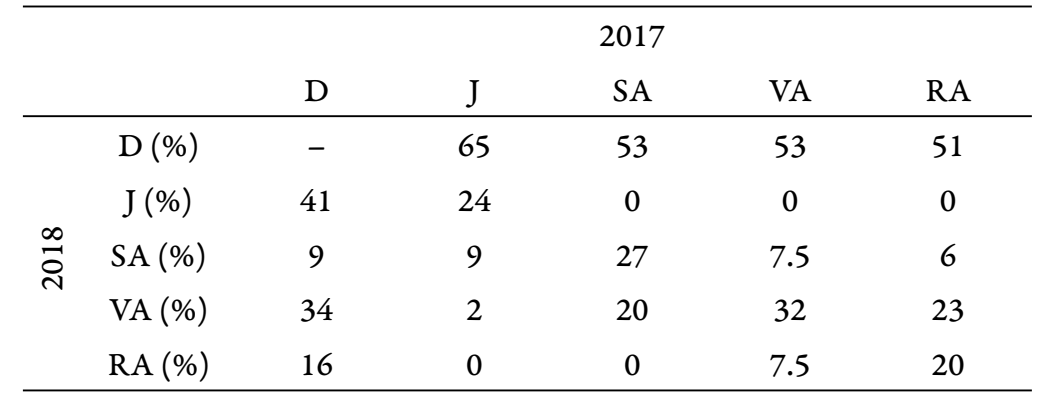

Table 5. Population flux from 2017 to 2018 in Tüskeszentpéter by the age-state of plants in 2017 ( $\mathrm{D}=$ dormant, $\mathrm{J}=$ juvenile, $\mathrm{SA}=$ subadult, $\mathrm{VA}=$ vegetative adult, $\mathrm{RA}=$ reproductive adult).

\begin{tabular}{ccccccc}
\hline & & \multicolumn{5}{c}{2017} \\
& & $\mathrm{D}$ & $\mathrm{J}$ & $\mathrm{SA}$ & $\mathrm{VA}$ & $\mathrm{RA}$ \\
\hline & $\mathrm{D}(\%)$ & - & 100 & 83 & 87 & 35 \\
$\stackrel{\mathrm{D}}{*}$ & $\mathrm{~J}(\%)$ & 0 & 0 & 0 & 0 & 0 \\
& $\mathrm{SA}(\%)$ & 7 & 0 & 0 & 4 & 3 \\
& $\mathrm{VA}(\%)$ & 66 & 0 & 17 & 7 & 11 \\
& $\mathrm{RA}(\%)$ & 27 & 0 & 0 & 2 & 51 \\
\hline
\end{tabular}


In Tüskeszentpéter most vegetative adults recorded in 2018 had been reproductive adult or dormant in 2017, only a few had been vegetative adults the year before (Table 7). In contrast in Gyékényes, most vegetative adults in 2018 had been in the same age-state the year before, and a few individuals became vegetative adults from all other age-states as well (Table 6). In both Tüskeszentpéter and Gyékényes vegetative adults mostly entered into dormancy, but in Gyékényes there were a considerable number of plants which stayed in vegetative-state as well (Tables 4 and 5).

A very high proportion (90.5\%) of individuals which were recorded as reproductive in 2018 had been in the same age-state the year before in Tüskeszentpéter (Table 7). In Gyékényes reproductive adults of 2018 were dormant, vegetative and reproductive adult in 2017 in roughly the same proportions (Table 6). Half of the reproductive adults remained in the same age-state next year and some became vegetative adult and dormant in Tüskeszentpéter (Table 5). In Gyékényes half of the reproductive adults next year entered into dormant state, but many be-

Table 6. Population flux from 2017 to 2018 in Gyékényes by the age-state of plants in 2018 ( $\mathrm{D}=$ dormant, $\mathrm{J}=$ juvenile, $\mathrm{SA}=$ subadult, $\mathrm{VA}=$ vegetative adult,

$\mathrm{RA}=$ reproductive adult).

\begin{tabular}{ccccccc}
\hline & & \multicolumn{5}{c}{2018} \\
& $\mathrm{D}$ & $\mathrm{J}$ & $\mathrm{SA}$ & $\mathrm{VA}$ & $\mathrm{RA}$ & \\
\hline \multirow{4}{*}{$\mathrm{D}(\%)$} & - & 62 & 16.6 & 22 & 27 & \\
& $\mathrm{~J}(\%)$ & 23 & 38 & 16.6 & 1.4 & 0 \\
& $\mathrm{SA}(\%)$ & 6.3 & 0 & 16.6 & 4.3 & 0 \\
& $\mathrm{VA}(\%)$ & 50 & 0 & 37.5 & 55 & 35 \\
& $\mathrm{RA}(\%)$ & 20.5 & 0 & 12.5 & 17 & 38 \\
\hline
\end{tabular}

Table 7. Population flux from 2017 to 2018 in Tüskeszentpéter by the age-state of plants in 2018 ( $\mathrm{D}=$ dormant, $\mathrm{J}=$ juvenile, $\mathrm{SA}=$ subadult, $\mathrm{VA}=$ vegetative adult, $\mathrm{RA}=$ reproductive adult).

\begin{tabular}{ccccccc}
\hline & & \multicolumn{6}{c}{2018} \\
& $\mathrm{D}$ & $\mathrm{J}$ & $\mathrm{SA}$ & $\mathrm{VA}$ & $\mathrm{RA}$ & \\
\hline \multirow{4}{*}{$\mathrm{D}(\%)$} & - & 0 & 17 & 41.5 & 7.5 & \\
& $\mathrm{~J}(\%)$ & 13 & 0 & 0 & 0 & 0 \\
& $\mathrm{SA} \mathrm{( \% )}$ & 6 & 0 & 0 & 4 & 0 \\
& $\mathrm{VA}(\%)$ & 44 & 0 & 33 & 13 & 2 \\
& $\mathrm{RA}(\%)$ & 37 & 0 & 50 & 41.5 & 90.5 \\
\hline
\end{tabular}


came reproductive or vegetative adults in fairly high proportion (23\% and $20 \%$, respectively) (Table 4 ).

In Gyékényes all individuals, which were recorded as juveniles in 2018 had been in juvenile and dormant state the year before (Table 6). There were individuals, which were juveniles in 2017 and became dormant, juvenile, subadult and vegetative adult as well, but no reproductive adults which had been juveniles the year before were found in 2018 (Table 6). In Tüskeszentpéter the number of juvenile individuals in 2017 was too low to investigate the population flux.

Half of the plants which were detected as subadult in 2018 had been reproductive adult and one-third of them were vegetative adult in the previous year in Tüskeszentpéter (Table 7). In Gyékényes individuals from every age-state entered into subadult state in 2018 (Table 6). A high proportion of the plants which had been recorded in 2017 as subadults entered into dormant state and a few entered into vegetative-state next year in both sites. There were some specimens, which remained subadult in Gyékényes (Tables 4 and 5).

\section{DISCUSSION}

There were significant differences in both years in the relative frequencies of leaf numbers. Individuals with higher number of leaves dominated in Tüskeszentpéter. It is possible that the prolonged flooding in 2018 influenced our results. We did not find any single-leaf plants, which might be the result of these circumstances in which they could not emerge or they had perished before our census and we were not able to find them in the lush vegetation. In connection with leaf number differences, the proportion of different age-states differed in the two sites considerably, e.g. the proportion of juveniles was much higher in Gyékényes.

Flowering plants usually had 5-6 leaves, but never more than 7 . We detected individuals with 8-9 leaves but these plants did not flower.

The percentage of reproductive plants was high in both years in Tüskeszentpéter, especially in 2017 (55\%). The proportions of reproductive individuals varied between $5.32 \%$ and $11.35 \%$ in different wet grassland and sedge communities in Romania (CSERGÖ \& FRIN K 2003). The proportion of adults (including both vegetative and reproductive adults) in mesic meadow sites ranged from 47 to $72 \%$ and in relatively wet meadows was significantly lower, varied from 27 to $46 \%$ in Sweden (ZHANG 1983). Although the proportion of flowering individuals showed marked rises and falls alternating in consecutive years in Sweden (ZHANG 1983), the biggest fluctuations in the number of individuals appearing above ground were recorded in juvenile and adult vegetative age-states in the largest England meadow population (TATAREN KO et al. 2013). 
Our hypothesis was that some traits could inform us about the age-state of the individuals, but there were not clear trends in leaf width or leaf length. Only the highest point showed that reproductive adults were consequently significantly higher than the other age-states.

Half of the reproductive adults flowered next year again in Tüskeszentpéter, but only $20 \%$ in Gyékényes. ZHANG (1983) reported 22-48\% from Sweden. Many (46.2-65.4\%) of the reproductive adults became vegetative in the next year in Sweden (ZHANG 1983), this ratio was $11 \%$ in Tüskeszentpéter and $23 \%$ in Gyékényes.

According to TATARENKo et al. (2013) transition to the dormancy is regular in all age groups. Similarly, transition to dormancy was high from subadult (53-83\%) and vegetative adult (53-87\%) age-state in our case. After flowering $35-52 \%$ were dormant in our sample areas, while $12 \%$ in Sweden (ZHANG 1983).

Some general conclusions could be drawn from our two-year study. We could not justify our hypothesis that some leaf traits may reflect the age-state of the individuals. There were remarkable differences in age-state ratios in our sampling sites, despite the relatively short distance between the two study sites compared to the extent of the distribution area of the species. The two populations could be characterised with their age-state structures, which may provide key information to the appropriate management of the sites. Since the rate of dormant individuals could be high, it is essential that each population should be monitored for some years before planning the management of a site.

Acknowledgements - The work is supported by the EFOP-3.6.3-VEKOP-16-2017-00008 project. The project is co-financed by the European Union and the European Social Fund.

Összefoglaló: Az eurázsiai elterjedésű kockásliliom (Fritillaria meleagris L.) areájának nagy részén veszélyeztetett faj. Mivel a faj legfőbb élőhelyét jelentő, folyóvizek mentén kialakult mocsárrétek felszántása, mezőgazdasági hasznosítás alá vonása következtében állományai megtizedelődtek, a megmaradt populációk megőrzése kiemelt fontosságú feladat. Ehhez azonban elengedhetetlen a faj életmenetének és populációdinamikájának lehető legpontosabb ismerete. A kockásliliom demográfiai szempontú vizsgálatainak jelentős része kvantitatív tulajdonságok alapján, különösen az egyes tövek leveleinek számából következtetett életmenet-állapotokat használt a csoportok elkülönítésére. Munkánk során egyrészt vizsgáltuk, hogy más kvantitatív tulajdonságok (pl. magasság, levélhossz, levélszélesség) is alkalmasak-e az egyes életmenet-állapotok pontosabb kategorizálására, illetve milyen mértékben hasonlítanak a demográfiai trendek két, a faj elterjedési területének méretéhez képest egymáshoz közeli élőhelyeken. E kérdések vizsgálatához a kockásliliom két nagyobb délnyugat-dunántúli állományában (Tüskeszentpéter és Gyékényes) 2017-ben jelöltünk ki két-két transzektet, melyekben az előforduló kockásliliom töveket egyedi azonosítókkal láttuk el és feljegyeztük a növények magasságát, leveleinek számát, a legfelső levél hosszát és szélességét és azt, hogy virágzott-e az egyed. Ezt a felmérést 2018-ban megismételtük, megjelölve az újonnan megjelent töveket is. A vizsgálat során négy életmenet-ál- 
lapottal számoltunk (juvenilis, szubadult, vegetatív adult és reproduktív adult). Megállapítottuk, hogy a két területre jellemző életmenet-állapotok eloszlása mindkét évben szignifikáns különbséget $(\alpha<0,001)$ mutattak egymástól, míg azonos területről, de eltérő évből származó eloszlások egyik esetben sem különböztek egymástól jelentősen. Az egyes életmenet-állapotok közül csupán a reproduktív tövek magassága különbözött szignifikánsan a másik három életmenet kategóriától, a leghosszabb levél hossza és a levélszélesség alapján nem különültek el az egyes állapotok egymástól. Minden életmenet-állapotból voltak egyedek, melyek a következő évben „hiányoztak”, feltehetően jelentős részük lappangott. A 2018-ban „újként” rögzített tövek többsége vegetatív adultként, egyhetede-egynegyede pedig reproduktív adultként jelent meg. A 2017-ben reproduktív tövek jelentős része (Gyékényes: 38\%, Tüskeszentpéter: 90,5\%) 2018-ban is reproduktívként jelent meg.

A vizsgált állományok közti demográfiai különbségek valamint a lappangó egyedek esetenkénti magas aránya arra mutat rá, hogy a kockásliliom állományok védelmi intézkedéseinek megtervezése előtt igen hasznos lenne az egyes populációk demográfiai jellemzőit feltárni.

\section{REFERENCES}

Biró É., Simon Zs. \& BóDIs J. (2018): A kockásliliom (Fritillaria meleagris L.) tüskeszentpéteri (Zalaszentgrót) élőhelyének tájhasználat története. - Kitaibelia 23(1): 25-30. https://doi.org/10.17542/kit.23.25

CSERGö A. M. \& Frink J. P. (2003): Some phytocoenological and population structure features of Fritillaria meleagris L. in the upper Şard Valley (Cluj county, Romania). - Contrib. Bot. Cluj 38(2): 163-172.

Gatsuk L. E., Smirnova O. V., Vorontzova L. I., Zaugolnova L. B. \& Ztiukova L. A. (1980): Age states of plants of various growth forms: a review. - J. Ecol. 68(2): 675-696. https://doi.org/10.2307/2259429

Grootjans A. P., Fresco L. F. M., Leeuw C. C. de \& Schipper P. C. (1996): Degeneration of species-rich Calthion palustris hay meadows; some considerations on the community concept. - J. Veget. Sci. 7: 185-194. https://doi.org/10.2307/3236318

Horsthuis M. A. P., Corporaal A., Schaminée J. H. J. \& Westhoff V. (1994): Die Schachblume (Fritillaria meleagris L.) in Nordwest-Europa, insbesondere in den Niederlanden: Ökologie, Verbreitung, pflanzensoziologische Lage. - Phytocoenologia 24: 627-647. https://doi.org/10.1127/phyto/24/1994/627

Ilijanić L. J., Stančić Z., Topić J. \& ŠEgulJa N. (1998): Distribution and phytosociological relationships of snake's-head (Fritillaria meleagris L.) in Croatia. - Acta Bot. Croat. 57: 65-88.

Kevey B. (2013): Adatok a hazai Dráva menti síkság flórájához. - Kitaibelia 18(1-2): 105-124.

Kevey B. (2018): Pótlások Magyarország edényes növényfajainak elterjedési atlaszához VII. Kitaibelia 23(2): 218-237. https://doi.org/10.17542/kit.21.227

KIRÁLY G. (ed.) (2007): Red list of the vascular flora of Hungary. - Private edition, Sopron, 73 pp. Magnes M., Drescher A. \& Nestroy O. (2013): Zur pflanzensoziologischen Eingliederung von Fritillaria meleagris - Beständen im Grenzbereich von Mittel- und Südosteuropa. - Tuexenia 33: $165-187$.

Mesterh Ázy A. (2013): A Rába-völgyi erdők élőhelyeinek és lágyszárú fajainak vizsgálata. - Tilia 17: $1-236$.

Tatrenko I., Dodd M., Rothero D. \& Gowing D. (2013): Citizen science in meadow studies: population dynamics in Fritillaria meleagris on North Meadow (Wiltshire, UK). - In: KURCHENKo E. I. \& TATRENKo I. V. (eds): Research and conservation of floodplain meadows. Proceedings of International Workshop, Kaluga, Russia, pp. 95-99. 
ZHANG L. (1983): Vegetation ecology and population biology of Fritillaria meleagris L. at the Kungsängen Nature Reserve, Eastern Sweden. - Acta Phytogeogr. Suecia 73: 3-92.

Zych M., STPICZyŃsKaAnd M. \& Roguz K. (2014): Pollination biology and breeding system of European Fritillaria meleagris L. (Liliaceae). - In: MÉRILlon J.-M., RAMAWAT K. G. \& ShivannA K. R. (eds): Reproductive biology of plants. CRC Press, Boca Raton, 147 pp.

(submitted: 28.10.2019, accepted: 13.11.2019) 